\title{
KEBIASAAN KONSUMSI MINUMAN DAN ASUPAN CAIRAN PADA ANAK USIA SEKOLAH DI PERKOTAAN
}

\author{
(Drinking Habits and Fluids Intakes of School Children in Urban)
}

Dodik Briawan ${ }^{1 *}$, Paramitha Rachma ${ }^{2}$, dan Kartika Annisa ${ }^{2}$

1 Departemen Gizi Masyarakat, Fakultas Ekologi Manusia, Institut Pertanian Bogor, Bogor 16680
2 Program Studi Gizi Masyarakat, Fakultas Ekologi Manusia (FEMA), IPB
* Alamat korespondensi: Departemen Gizi Masyarakat, Fakultas Ekologi Manusia, Institut Pertanian Bogor,
Bogor 16680. Telp: 0251-8621258; Fax: 0251-8622276; Email: dbriawan@yahoo.com

\begin{abstract}
ABST RACT
The study objectives were to analyze the food and beverages contribution to the total fluid intake, and the sign of mild dehydration of school age children. The cross-sectional study was applied to 78 boys and 78 girls of elementary school students in Bogor City. Two days food recall was applied to estimate fluid intake. The fluid intake was a summation of various food and beverages. The result showed beside of plain water, most of the school children used to consumed milk and tea (>70\%) at home. The total fluid intake was $2283 \mathrm{~mL}$ for boys and 2024 $\mathrm{mL}$ for girls, and its contribution was 21 percent from food $(430-490 \mathrm{~mL})$ and 78 percent from beverages (1600-1800 mL). There are 67.4 percent boys and 62.8 percent girls suffered mild dehydration with minimum three physical signs of dehydration. There are still 18.6 percent boys and 3.5 percent girls that their fluid intake bel ow $100 \%$ of the requirement.
\end{abstract}

Key words: beverage, food, fluid intake, school children

\section{PENDAHULUAN}

Air merupakan senyawa esensial yang keberadaannya sangat diperlukan untuk proses kehidupan. Tubuh manusia terdiri dari 55-75 persen air. Kondisi keseimbangan cairan dalam tubuh yang negatif atau biasa disebut dehidrasi (penurunan cairan 2-6\%). Dehidrasi disebabkan oleh penurunan asupan air, peningkatan pengeluaran air (melalui ginjal, saluran pencernaan dan lainnya), ataupun perubahan cairan. Penurunan pada total cairan dalam tubuh akan menyebabkan terjadinya penurunan volume cairan intraseluler maupun ekstraseluler. Perwujudan klinis dari dehidrasi kebanyakan dikaitkan dengan penurunan volume intravaskular yang akan menyebabkan terjadinya kegagalan fungsi organ dan akhirnya kematian (Sawka, Cheuvront, \& Carter 2005).

Rasa haus merupakan indikasi awal dan yang paling sederhana sebagai tanda terjadinya dehidrasi ringan. Namun demikian, air tidak hanya dibutuhkan pada saat tubuh merasa haus, tapi air merupakan salah satu zat gizi yang penting. Air mempunyai berbagai peranan yang penting dalam tubuh, diantaranya sebagai pelarut, katalisator, pelumas, pengatur suhu tubuh serta sebagai penyedia mineral dan elektrolit dalam tubuh (FNRI 2002; Whitmire 2004).
Kebutuhan cairan tiap individu akan sangat bervariasi, tergantung pada aktivitas fisik, umur, berat badan, iklim (suhu) serta diet (asupan makanan). Salah satu pesan dari Pesan Dasar Umum Gizi Seimbang (PUGS) adalah minum air dalam jumlah yang cukup dan aman (Departemen Kesehatan 2005). Dalam pedoman tersebut, orang dewasa disarankan untuk mengonsumsi minimal 2 liter atau 8 gelas air minum setiap hari dalam kondisi lingkungan normal untuk memenuhi kebutuhan cairan tubuh serta menjaga kese-hatan.

Pada Widya Karya Nasional Pangan dan Gizi Pada Widya Karya Nasional Pangan dan Gizi tahun 2004 (WNPG-LIPI) telah didiskusikan besarnya angka kecukupan air dan elektrolit bagi orang Indonesia (Proboprastowo \& Dwiriani 2004). Angka kecukupan air berkisar antara 0.8-2.8 liter per hari, tergantung pada umur, jenis kelamin, aktivitas, dan suhu. Meskipun demikian, diduga masih banyak masyarakat mengonsumsi air dalam jumlah kurang dibandingkan dengan kebutuhannya.

Meskipun air termasuk dalam salah satu zat gizi, tapi ada kecenderungan di masyarakat untuk mengabaikan peranannya dalam menjaga kesehatan. Politeknik Tamasek dan AFIC (1998) melakukan penelitian di Singapura yang menunjukkan masih banyak diantara remaja dan orang dewasa yang mengalami dehidrasi. Studi di Indonesia ditemukan sebanyak 
49.5 persen remaja dan 42.5 persen dewasa meng-alami dehidrasi ringan (Hardinsyah et al. 2009). Dengan membandingkan antara dua daerah dengan agroekologi berbeda menunjukkan prevalensi dehidrasi ringan lebih tinggi di dataran rendah (53\%) daripada di dataran tinggi (39\%). Belum banyak studi kebiasaan minum dan asupan cairan pada kelompok anak sekolah (school children), sehingga tidak banyak informasi dari jurnal yang dapat dikaji. Padahal dehidrasi ringan, yaitu kehilangan kehilangan cairan tubuh 1-2 persen dapat menyebabkan gangguan fungsi kognitif, kurang konsentrasi, dan menurunnya kapasitas fisik (J equier \& Constant 2010).

Tujuan penelitian secara umum adalah untuk mengkaji kebiasaan minum dan asupan cairan pada siswa dan siswi anak usia sekolah dasar. Adapun tujuan khusus penelitian adalah mengkaji: 1) kebiasaan konsumsi minuman, 2) kontribusi asupan cairan dari makanan dan minuman, 3) tingkat kecukupan cairan tubuh, dan 4) tanda fisik dehidrasi subyektif.

\section{METODE}

\section{Desain dan Lokasi}

Desain penelitian ini adalah cross-sectional study. Penelitian dilakukan di SD Polisi 4 Kota Bogor yang ditetapkan secara purposive, dengan pertimbangan berada di tengah kota, sekolah favorit, jumlah siswa banyak, dan berasal dari keluarga dengan sosial ekonomi menengah. Pengumpulan data dilakukan pada bulan Mei-J uni 2009.

\section{Cara Pemilihan Sampel}

J umlah minimum sampel dihitung berdasarkan estimasi mean, dengan asumsi $a=90$ persen, $\mathrm{sd}=900 \mathrm{~mL}$ (Hardinsyah et al. 2009), $\mathrm{d}=20$ persen, sehingga diperoleh minimal 78 anak sekolah atau diambil 172 siswa dan siswi. Kriteria sampel adalah tidak sedang menderita penyakit diare, ginjal, demam berdarah, flu (demam) serta radang tenggorokan. Sampel tersebut diambil secara acak dari 362 murid kelas 4 dan 5 yang dijinkan oleh sekolah untuk diteliti.

\section{J enis dan Cara Pengumpulan Data}

Data yang dikumpulkan meliputi karakteristik sampel seperti umur, berat badan, tinggi badan, dan jumlah uang saku. Berat dan tinggi badan sampel diukur dengan timbangan injak dan microtoise.
Kebiasaan konsumsi minuman sampel dikumpulkan melalui wawancara dengan FFQ (food frequency questionnaire) selama seminggu terakhir. Data konsumsi minuman meliputi jenis, merk, dan jumlahnya (porsi). Untuk menghitung asupan cairan dengan metode food recall 2×24 jam makanan dan minuman pada hari sekolah dan hari libur.

Tanda dehidrasi sampel secara subyektif dinilai dari keluhan haus, lelah, kulit kering, mulut dan tenggorokan kering pada periode waktu satu minggu (AFIC 2000). Sampel dianggap dehidrasi ringan jika mengalami minimal tiga tanda dehidrasi, dan tidak dehidrasi jika kurang dari tiga tanda dehidrasi.

Kebutuhan air dihitung berdasarkan rekomendasi dari The National Research Council (NRC) dalam Sawka et al. (2005) yaitu $1 \mathrm{~mL} /$ kkal untuk anak-anak dan dewasa. Penilaian status gizi sampel dilakukan menggunakan Anthro Plus dengan indeks IMT/ U (WHO 2007).

\section{HASIL DAN PEMBAHASAN}

\section{Karakteristik Sampel}

Usia sampel antara 9-12 tahun, dengan persentase terbesar berusia 11 tahun yaitu 53 persen. Rata-rata berat badan sampel siswa $39.0 \pm 12.4 \mathrm{~kg}$ dengan tinggi badan 139.3 \pm 8.5 $\mathrm{cm}$, sedangkan siswi $34.4 \pm 7.9 \mathrm{~kg}$ dan tinggi badan $140.1 \pm 8.3 \mathrm{~cm}$. Berdasarkan indeks IMT, sebanyak 50 persen siswa dan 68.8 persen siswi memiliki status gizi normal. Lebih banyak siswa yang overweight dan obese (47.8\%) dibandingkan siswi (30.9\%). Sebaliknya yang menderita underweight dan severe underweight lebih banyak (10.5\%) siswa dibandingkan siswi $(2.4 \%$.

Sampel siswa dan siswi kebanyakan berasal dari keluarga kelas menengah. Kepala keluarga sampel dengan tingkat pendidikan sarjana (S1) sebanyak 47.1 persen, bahkan ada yang berpendidikan pascasarjana sebanyak 27.4 persen. Rata-rata uang saku siswa dan siswi sebesar Rp 150000 per bulan. Jenis minuman yang banyak dibeli siswa dan siswi dengan kategori murah adalah berharga $\mathrm{Rp}$ 1 000-1 500, seperti Teh Gelas, Ale-ale, Muntea, es Milo, Nutrisari, Teh Sisri, es blender (Pop Ice) dan sebagainya.

\section{Kebiasaan Konsumsi Minuman}

Jenis minuman yang dikonsumsi sampel dibedakan menjadi air putih, susu nonkemasan dan kemasan, teh non kemasan dan 
kemasan, kopi, sirup non kemasan dan kemasan, jus buah non kemasan dan kemasan, minuman isotonik, soft drink, es blender serta jenis minuman lainnya. Yang dimaksud dengan minuman non-kemasan adalah jika minuman tersebut dibuat atau disiapkan di rumah tangga, seperti susu bubuk, teh celup, jus buah. Jenis minuman yang paling sering diminum oleh kebanyakan sampel (>70\%) adalah air putih, susu, dan teh dibandingkan jenis minuman lainnya.

Minuman larangan adalah jenis minuman yang sebaiknya tidak diminum atas anjuran dokter, guru ataupun orang tua. Sebanyak 51.2 persen sampel tidak memiliki minuman larangan, dan 48.8 persen memiliki minuman larangan seperti es, minuman dengan pewarna buatan, soft drink dan minuman lainnya. Sebesar 4.7 persen sampel memiliki jenis minuman kesukaan yang dilarang oleh orang tuanya. Keterbatasan pengawasan orang tua tidak dapat mencegah sampel untuk mengonsumsi minuman yang dilarang, seperti soft drink dan minuman es.

Saat di lingkungan sekolah, sebagian besar siswa (68.6\%) dan siswi (55.8\%) minum dengan frekuensi 3-4 kali per hari. Sebagian besar sampel minum pada waktu jam istirahat, membeli minuman di sekolah (73.3\%), dan sisanya membawa bekal dari rumah. Jenis aktivitas yang mendorong sampel untuk minum adalah setelah kegiatan olah raga. Di sekolah, sampel lebih menyukai jenis minuman yang "berasa" dari pada air putih (plain water).

Kebiasaan minum saat di sekolah hanya 20.9 persen siswi dan 10.5 persen siswa yang menyukai air putih. Sementara sebagian besar sampel (54.7\% siswa dan $36.0 \%$ siswi) menyu- kai teh kemasan. Adapun merek teh yang disukai adalah Teh Kotak, Fruit Tea, dan Teh Sosro. Hanya 7 persen siswa dan 14 persen siswi yang menyatakan menyukai minuman susu, dan jumlah tersebut hampir sama dengan kesukaan terhadap soft drink 8.2 persen (siswa) dan 7.0 persen (siswi).

Kebiasaan minum (beverages) berikut ini dihitung dari frekuensi minuman satu minggu sebelumnya. Konsumsi air putih lebih banyak pada siswa dibandingkan siswi, yaitu berturut-turut $9791.6 \pm 3337.6 \mathrm{~mL}$ dan $7804.3 \pm$ $1634.5 \mathrm{~mL}$ per minggu. Kurang lebih 70 persen sampel mengonsumsi susu (1900-2300 mL) dan teh (1900-2200 mL). J enis susu tersebut terutama adalah susu bubuk, yang diseduh dengan air putih dan disiapkan di rumah. Jenis minuman lainnya yang kontribusinya relatif kecil adalah jus buah, sirup, soft drink, dan es blender (150-500 mL) (Tabel 1).

\section{Kontribusi Asupan Cairan dari Makanan dan Minuman}

Penilaian asupan cairan dilakukan dengan recall $2 \times 24$ jam pada hari anak ke sekolah dan hari libur (mL/hari). Whitmire (2004) menyatakan bahwa sumber asupan cairan tubuh berasal terutama dari makanan dan minuman. Sebagian besar sampel mengonsumsi pangan pokok, lauk hewani, serta sayur dan buah. Dari makanan padat tersebut, pangan pokok merupakan jenis pangan yang memberikan kontribusi paling banyak terhadap asupan cairan dibandingkan dengan jenis pangan lainnya, yaitu sebesar 260.4+109.0 mL (siswa) dan 218.3 $\pm 48.0 \mathrm{~mL}$ (siswi). J enis pangan pokok sampel adalah nasi, bubur, roti putih, dan biskuit.

Tabel 1. Sebaran Sampel dan Rataan Konsumsi Minuman Seminggu yang Lalu

\begin{tabular}{|c|c|c|c|c|c|c|}
\hline \multirow{3}{*}{ J enis Minuman } & \multicolumn{4}{|c|}{ J umlah sampel } & \multicolumn{2}{|c|}{ Kon̄sumsi (mL/minggu) ${ }^{*}$} \\
\hline & \multicolumn{2}{|c|}{ Siswa } & \multicolumn{2}{|c|}{ Siswi } & \multirow{2}{*}{ Siswa } & \multirow{2}{*}{ Siswi } \\
\hline & $\mathbf{n}$ & $\%$ & $\mathbf{n}$ & $\%$ & & \\
\hline Air putih & 86 & 100.0 & 86 & 100.0 & $9791.6 \pm 3337.6$ & $7804.3 \pm 1634.5$ \\
\hline Susu non kemasan & 67 & 77.9 & 73 & 84.9 & $1642.3 \pm 1491.8$ & $1717.9 \pm 1402.7$ \\
\hline Susu kemasan & 45 & 52.3 & 68 & 79.1 & $351.9 \pm 563.1$ & $590.2 \pm 764.9$ \\
\hline Teh non kemasan & 55 & 64.0 & 74 & 86.0 & $876.9 \pm 1231.9$ & $795.4 \pm 654.6$ \\
\hline Teh kemasan & 66 & 76.7 & 65 & 75.6 & $654.2 \pm 607.5$ & $504.2 \pm 469.9$ \\
\hline Kopi & 14 & 16.3 & 12 & 14.0 & $55.8 \pm 137.4$ & $55.8 \pm 164.1$ \\
\hline Sirup non kemasan & 28 & 32.6 & 62 & 72.1 & $205.1 \pm 309.6$ & $373.5 \pm 507.2$ \\
\hline Sirup kemasan & 25 & 29.1 & 25 & 29.1 & $106.4 \pm 198.0$ & $98.8 \pm 194.2$ \\
\hline J us buah non kemasan & 25 & 29.1 & 64 & 74.4 & $281.9 \pm 350.6$ & $533.0 \pm 581.7$ \\
\hline J us buah kemasan & 32 & 37.2 & 40 & 46.5 & $164.6 \pm 245.4$ & $188.9 \pm 265.5$ \\
\hline Minuman Isotonik & 15 & 17.4 & 25 & 29.1 & $98.3 \pm 240.2$ & $186.0 \pm 344.5$ \\
\hline Soft drink & 52 & 60.5 & 52 & 60.5 & $299.0 \pm 351.3$ & $312.6 \pm 360.0$ \\
\hline Es blender & 21 & 24.4 & 20 & 23.3 & $231.4 \pm 508.4$ & $154.8 \pm 342.8$ \\
\hline Minuman Iainnya & 24 & 27.9 & 19 & 22.1 & $115.8 \pm 306.5$ & $82.0 \pm 255.7$ \\
\hline
\end{tabular}

Keterangan: ${ }^{*} \mathrm{x} \pm \mathrm{sd}$ adalah rata-rata dan standar deviasi 
Sayur dan buah merupakan jenis pangan berikutnya yang memberikan kontribusi cairan besar setelah pangan pokok, yaitu 110.6 $6 \pm 107.8$ $\mathrm{mL}$ (siswa) dan $111.6 \pm 94.0 \mathrm{~mL}$ (siswi). Tidak semua sampel mengonsumsi sayur dan buah, yaitu hanya sebesar 25.6 persen (siswa) dan 20.9 persen (siswi). Asupan cairan dari sayur dan buah memberikan jumlah yang lebih besar dibandingkan dengan lauk hewani. J enis sayur yang dikonsumsi antara lain bayam, sop, kangkung, dan buncis, labu siam; sedangkan jenis buah antara lain semangka, apel, jeruk, meIon, dan pepaya.

Rata-rata asupan cairan yang berasal dari lauk hewani adalah $79.0 \pm 37.6 \mathrm{~mL}$ (siswa) dan $76.7 \pm 42.4 \mathrm{~mL}$ (siswi). Seluruh sampel mengonsumsi lauk hewani, jenisnya antara lain ayam, daging sapi, udang serta ikan laut dan tawar. Rata-rata asupan cairan yang berasal dari makanan sepinggan, jajanan, lauk nabati dan pangan lain-lain nilainya sangat kecil karena tidak banyak sampel yang mengonsumsinya. Kontribusi asupan cairan dari kelompok makanan tersebut disajikan pada Tabel 2 berikut.

Tabel 2. Kontribusi Asupan Cairan dari Kelompok Makanan

\begin{tabular}{lcc}
\hline \multicolumn{1}{c}{$\begin{array}{c}\text { Kelompok } \\
\text { makanan }\end{array}$} & \multicolumn{2}{c}{ Asupan cairan (mL/hari) ${ }^{*}$} \\
\cline { 2 - 3 } & Siswa & Siswi \\
\hline Makanan pokok & $260.4 \pm 109.0$ & $218.3 \pm 48.0$ \\
Lauk hewani & $79.0 \pm 37.6$ & $76.7 \pm 42.4$ \\
Lauk nabati & $9.8 \pm 22.4$ & $8.7 \pm 23.3$ \\
Sayur dan buah & $110.6 \pm 107.8$ & $111.6 \pm 94.0$ \\
Makanan sepinggan & $9.7 \pm 25.6$ & $7.3 \pm 26.1$ \\
Makanan jajanan & $19.4 \pm 49.8$ & $3.9 \pm 13.1$ \\
Lain-lain & $3.4 \pm 14.4$ & $5.5 \pm 17.6$ \\
\hline Total & $492.3 \pm 161.9$ & $426.6 \pm 126.0$ \\
\hline
\end{tabular}

${ }^{*} \mathrm{x} \pm$ sd adalah rata-rata dan standar deviasi

Asupan cairan yang berasal dari minuman lain seperti sirup, kopi, jus buah, minuman isotonik, soft drink, es blender dan lainnya kontribusinya relatif kecil. Rata-rata total asupan cairan yang berasal dari kelompok minuman adalah $1791.0 \pm 452.5 \mathrm{~mL}$ siswa dan 1597.8+243. $0 \mathrm{~mL}$ siswi.

Rata-rata asupan cairan yang berasal dari aneka jenis minuman (beverages) terbesar adalah berasal dari air putih. Rata-rata asupan cairan yang berasal dari air putih ada-

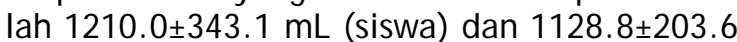
$\mathrm{mL}$ (siswi). Kontribusi terbesar berikutnya adalah susu, yaitu $271.7 \pm 211.5 \mathrm{~mL}$ (siswa) dan $251.9 \pm 164.0 \mathrm{~mL}$ (siswi), dan kontribusi dari teh berturut-turut sebesar $176.0 \pm 237.9 \mathrm{~mL}$ dan $113.9 \pm 168.5 \mathrm{~mL}$. Apabila dihitung kontribusi asupan minuman selain air putih terhadap total asupan minuman adalah sebesar 30 persen. Di Amerika Serikat (AS) terjadi peningkatan konsumsi terhadap minuman yang banyak mengandung kalori (sweetened beverages), yang memberikan kontribusi 20 persen penyebab obesitas (Woordward-Lopez et al. 2010). Kontribusi asupan cairan dari berbagai kelompok minuman disajikan pada Tabel 3 berikut.

Tabel 3. Kontribusi Asupan Cairan dari Kelompok Minuman

\begin{tabular}{|c|c|c|}
\hline \multirow{2}{*}{ Kelompok minuman } & \multicolumn{2}{|c|}{ Asupan cairan (mL/hari) ${ }^{*}$} \\
\hline & Siswa & Siswi \\
\hline Air putih & $1210.0 \pm 343.1$ & $1128.8 \pm 203.6$ \\
\hline Susu & $271.7 \pm 211.5$ & $251.9 \pm 164.0$ \\
\hline Teh & $176.0 \pm 237.9$ & $113.9 \pm 169.5$ \\
\hline Kopi & $16.7 \pm 69.2$ & $8.4 \pm 54.6$ \\
\hline Sirup & $2.8 \pm 25.8$ & $12.6 \pm 58.3$ \\
\hline J us buah & $15.3 \pm 77.6$ & $26.5 \pm 88.6$ \\
\hline Minuman Isotonik & $12.3 \pm 57.9$ & $7.6 \pm 49.4$ \\
\hline Soft drink & $25.7 \pm 76.3$ & $17.4 \pm 71.7$ \\
\hline Es blender & $44.6 \pm 141.4$ & $8.4 \pm 54.6$ \\
\hline Minuman Iainnnya & $15.7 \pm 80.0$ & $4.0 \pm 39.3$ \\
\hline Total cairan minuman & $1791.0 \pm 452.5$ & $1597.8 \pm 243.0$ \\
\hline Total asupan cairan & $2283.4 \pm 468.1$ & $2024.4 \pm 287.4$ \\
\hline
\end{tabular}

Survey di Singapura menunjukkan sumber cairan tubuh utama adalah air putih (74\%). Minuman teh dan kopi berada di urutan kedua $(32 \%)$, dan selanj utnya minuman ringan (17\%). Sumber cairan lainnya adalah dari buah dan salad (AFIC 2002). Survey di AS menunjukkan asupan cairan (fluid) ke dalam tubuh sebesar $1764 \mathrm{~mL}$ per hari, dengan rincian air putih 673 $\mathrm{mL}$, susu $312 \mathrm{~mL}$, teh dan kopi $360 \mathrm{~mL}$, dan minuman ringan $420 \mathrm{~mL}$ per hari (Kleiner 1999).

Kontribusi asupan cairan dari kelompok makanan dan minuman antara siswa dan siswi sekolah dasar relatif tidak berbeda. Rata-rata kontribusi asupan cairan pada siswa yang berasal dari makanan adalah $22.1 \pm 7.7$ persen, dan dari minuman adalah $77.9 \pm 7.7$ persen. $\mathrm{Pa}$ da siswi kontribusi asupan cairan yang berasal dari makanan $21.2 \pm 5.2$ persen (selang 13.4$36.1 \%$, dan dari minuman sebesar $78.8 \pm 5.2$ persen (selang 63.9-86.6\%). Jika dibandingkan dengan data NHANES di AS, dari total asupan cairan kontribusi terbesar berasal dari minuman (beverages) 49-63 persen, air minum (putih) 35-54 persen, dan makanan pa-dat 19-25 persen (IOM 2004). Di Eropa, untuk menu orang dewasa kontribusi cairan tubuh berasal dari makanan 20-30 persen dan dari minuman 60-70 persen (J equier \& Constant 2010). 


\section{Tingkat Kecukupan Cairan}

Rata-rata asupan cairan yang berasal dari makanan adalah sebesar $492.3 \pm 161.9 \mathrm{~mL}$ siswa dan $426.6 \pm 126.0 \mathrm{~mL}$ siswi. Sedangkan rata-rata asupan cairan yang berasal dari minuman berturut-turut sebesar $1791.0 \pm 452.5$ $\mathrm{mL}$ dan $1597.8 \pm 243.0 \mathrm{~mL}$. Sehingga rata-rata total asupan cairan adalah $2283.4 \pm 468.1 \mathrm{~mL}$ (siswa) dan 2024.4+287.4 mL (siswi).

Rata-rata kebutuhan cairan yang dihitung berdasarkan The National Research Council (NRC) di dalam Sawka et al. (2005) untuk siswa adalah $1735.0 \pm 282.7 \mathrm{~mL}$ dan untuk siswi adalah $1516.7 \pm 125.3 \mathrm{~mL}$. Angka kebutuhan tersebut lebih rendah dibandingkan dengan kebutuhan kelompok umur 9-13 tahun di AS untuk laki-laki sebesar $2400 \mathrm{~mL}$ dan perempuan $2100 \mathrm{~mL}$ per hari, sedangkan untuk Eropa berturut-turut $2100 \mathrm{~mL}$ dan $1900 \mathrm{~mL}$ (J equier \& Constant 2010). Tingkat pemenuhan cairan merupakan perbandingan antara total asupan dengan kebutuhan cairan. Jika dibandingkan, maka rata-rata kebutuhan tersebut relatif sudah terpenuhi oleh asupan cairan dari makanan dan minuman (Tabel 4).

Tabel 4. Tingkat Pemenuhan Kebutuhan Cairan

\begin{tabular}{lcc}
\hline Tingkat Kecukupan & Siswa & Siswi \\
\hline $\begin{array}{l}\text {-Kebutuhan cairan } \\
\text { (mL/ hari) }\end{array}$ & $1735.0 \pm 282.7$ & $1516.7 \pm 125.3$ \\
$\begin{array}{l}\text {-Asupan cairan } \\
\text { (mL/ hari) }\end{array}$ & $2283.4 \pm 468.1$ & $2024.4 \pm 287.4$ \\
$\begin{array}{l}\text {-Pemenuhan kebutuhan } \\
\text { cairan (\%) }\end{array}$ & $134.6 \pm 33.2$ & $132.8 \pm 20.6$ \\
\hline
\end{tabular}

Meskipun rata-rata kebutuhan cairan tersebut sudah terpenuhi, masih terdapat 18.6 persen siswa dan 3.5 persen siswi yang kebutuhannya masih di bawah 100 persen. Total asupan cairan berasal dari makanan dan minuman, namun cara untuk menghitung asupan cairan dari minuman akan lebih mudah dari pada menghitung total asupan. Evaluasi lebih lanjut apabila asupan cairan dihitung dari minuman saja, maka terdapat 46.5 persen siswa dan 45.3 persen siswi asupan cairan di bawah 100 persen. Dan jika hanya dihitung dari air putih saja, maka terdapat 70.9 persen siswa dan 49.0 persen siswi asupannya di bawah $2000 \mathrm{~mL}$.

Terdapat berbagai alasan tidak tercukupinya kebutuhan cairan tubuh tersebut. Sebanyak 70 persen sampel baru minum setelah merasa haus, dan sebenarnya ini sudah terlambat karena haus merupakan indikasi awal dari dehidrasi. Alasan yang paling sering dijumpai dari ketidakcukupan minum adalah karena: 1) tidak haus, 2) lupa minum, 3) merepotkan, dan 4) tidak mau sering ke kamar kecil (AFIC 2000).

\section{Tanda-tanda Dehidrasi Ringan}

Pada anak SD ditemukan bahwa sebagian besar sampel (66.3\%) akan minum pada saat haus. Hanya sedikit sampel yang minum saat sebelum haus (5.8\%). Hal ini sama dengan studi di Singapura yang menemukan sebagian besar subyek hanya minum ketika merasa haus. Namun sebenarnya haus merupakan tanda awal bahwa tubuh mengalami dehidrasi ringan (AFIC 2000). Penilaian terhadap kecenderungan dehidrasi dilakukan secara subyektif berdasarkan pada mengelompokkan tanda-tanda fisik dehidrasi. Sampel digolongkan dehidrasi ringan apabila mengalami minimal tiga dari tanda-tanda fisik dehidrasi. Sebesar 67.4 persen siswa dan 62.8 persen siswi kemungkinan mengalami dehidrasi ringan.

Beberapa indikator yang dapat digunakan untuk mengukur status hidrasi, antara lain keseimbangan masukan-keluaran air, perubahan berat badan, plasma, dan urin. Shireffs (2003) menyebutkan pengukuran dehidrasi yang dianggap valid adalah urine specific gravity dan osmolalitas plasma. Di kalangan dokter, teknik sederhana yang sering digunakan adalah menggunakan perubahan warna urin (J equier \& Constant 2010).

\section{KESIMPULAN}

Selain air putih, sebagian besar anak sekolah dasar terbiasa minum susu dan teh $(>70 \%)$. Ketiga minuman tersebut biasa diminum di rumah, sedangkan di sekolah mereka lebih menyukai minuman yang "berasa" seperti teh kemasan dan softdrink.

Rata-rata kontribusi asupan cairan pada anak sekolah dasar yang berasal dari makanan sekitar 21 persen dan dari minuman 78 persen. Total asupan cairan rata-rata adalah $2283 \mathrm{~mL}$ (siswa) dan 2024 mL (siswi). Rata-rata asupan cairan yang berasal makanan $430-490 \mathrm{~mL}$, sedangkan dari minuman 1600-1800 mL.

Kebutuhan cairan tubuh rata-rata anak sekolah dasar sudah terpenuhi (133\%), namun demikian masih terdapat 18.6 persen siswa dan 3.5 persen siswi yang masih di bawah kebutuhannya $(<100 \%)$. Jika hanya dihitung dari asupan air putih saja, bahkan masih terdapat 70.9 persen siswa dan 49.0 persen siswi asupannya di bawah $2000 \mathrm{~mL}$. Terdapat sebanyak 67.4 persen siswa dan 62.8 persen siswi ke- 
mungkinan mengalami dehidrasi ringan dengan mengalami minimal tiga dari tanda-tanda fisik dehidrasi.

Tanda-tanda dehidrasi sering diabaikan karena tidak disadari oleh anak sekolah. Dalam membawa bekal makanan dari rumah maupun alokasi uang jajan siswa, sebaiknya memasukkan minuman (air putih/teh/susu) agar anak terhindar dari dehidrasi.

\section{DAFTAR PUSTAKA}

AFIC [Asia Food Information Center]. 2002. Fluid the forgotten factor. Singapore.

Briawan D, Hardinsyah, \& Sunaryo E. Fluid intake of adolescents living in coastal and mountanious areas. Abstracts 19th International Congress of Nutrition, 2009 October 4-9, Bangkok.

[Depkes] Departemen Kesehatan RI. 2005. Panduan 13 Pesan Dasar Gizi Seimbang. Departemen Kesehatan Republik Indonesia, J akarta.

[FNRI] Food and Nutrition Research Institute. 2002. Recommended Energy and Nutrient Intakes, Phillippines.

Hardinsyah et al. 2009. Studi Kebiasaan Minum and Status Hidrasi pada Remaja dan Dewasa di Dua Wilayah Ekologi yang Berbeda. Pergizi Pangan dan Departemen Gizi Masyarakat, Fakultas Ekologi Manusia, IPB, Bogor.

J equier $\mathrm{E} \&$ Constant F. 2010. Water as an essential nutrient: the physiological basis of hydration. Europian J ournal of Clinical Nutrition, 64, 115-123.
Manz F \& A Wentz. 2003. 24-h-Hydration status: parameters, epidemiology and recommendation. Europ J Clinic Nutr, 57, S10-S18.

Mahan K. \& Stump E. 2004. Food, Nutrition, and Diet Therapy. Elsevier, Health Science Right, USA.

Proboprastowo SM \& Dwiriani CM. 2004. Angka Kecukupan Air dan Elektrolit. Prosiding Widya Karya Nasional Pangan dan Gizi, J akarta.

Sawka MN et al. 2000. Effects of dehydration and rehydration on performance. In Nutrition in sport, ed. Maughan RJ. Blackwell Science, Oxford.

Cheuvront SN, \& Carter C. 2005. Human water needs. Nutr Rev, Jun 2005 (63) 63-6.

Shirrefs SM. 2003. Markers of Hydration Status. Europoan J ournal of Clinical Nutrition, 57, supl 2.

[TP/AFIC] Temasek Polytechnic, AFIC. 1998. Singapore drinking habits survey, Singapore.

Whitmire SJ. 2004. Water, electrolytes, and acid-base balance. In Mahan and Escott-Stump ed. Food, Nutrition and Diet Therapy. WB Saunders, USA.

Woordward-Lopez G, Kao J , \& Ritchie L. 2010. To what extend the sweteened beverages contributed to the obesity epidemic?. Public Health Nutrition, 111. 